MEDEDELING 43

Deze publikatie verschijnt tevens als Mededeling 448 van het IPO te Wageningen. 


\title{
CONTROL OF STEM NEMATODE ATTACK IN ONIONS WITH 0,0-DIETHYL 0-2 PYRAZINYLPHOSPHOROTHIOATE ("ZINOPHOS") AND 0-PHENYL N,N' DIMETHYLPHOSPHORODIAMIDE ("NELLITE")
}

\author{
BY \\ C. KAAI \\ Instituut voor Plantenziektenkundig Onderzoek, Wageningen, Stationed at the Proefstation voor de \\ Groenteteelt in de vollegrond, Alkmaar, The Netherlands
}

In a field experiment on sandy loam, application of 0,0-diethyl 0.2 pyrazinylphosphorothioate ("Zinophos") 3 weeks after onions had been sown, gave a better control of attack by the stem nematode than treatments 10 days before or 6 weeks after sowing.

The treatment was as effective as application of a contact nematicide that would have killed more than $99 \%$ of the nematodes. At low initial nematode densities the effect of the treatment on population density after harvest was comparable to that of a contact nematicide that would have killed $98 \%$ of the nematodes. This figure was higher the greater the initial density of the nematode. Of the onions that still looked healthy at harvest time $25 \%, 21 \%$ and $36 \%$ (in the order of the dates of treatment) developed symptoms of attack during storage.

Application of $1.7 \mathrm{~g}$ per $\mathrm{m}^{2}$ of 0-phenyl $\mathrm{N}, \mathrm{N}^{\prime}$ dimethylphosphorodiamide ("Nellite") at the dates mentioned above had only a slight effect on the attack of onions by the stem nematode.

According to den Ouden \& Kaai (1963) application of Nemafos (5\% 0,0diethyl 0-2 pyrazinylphosphorothioate) to the soil reduced the rate of multiplication of Heterodera rostochiensis on potatoes and the damage to onions by Ditylenchus dipsaci. Treatments were carried out at three dates. The earliest was the most effective (i.e. 3 weeks after the planting of the potatoes and 6 weeks after the sowing of the onions). Repetition of treatments did not materially improve the result of the earliest treatment of the series. The effect of even earlier treatments with 0,0-diethyl 0-2 pyrazinylphosphorothioate and also with 0 -phenyl $\mathbf{N}, \mathrm{N}^{\prime}$ dimethylphosphorodiamide ("Nellite") on the proportions of diseased onions at different densities of stem nematodes was investigated in a field experiment in 1963.

\section{Design of the experiment}

The effectiveness of a soil treatment with a contact nematicide is best expressed by the rate of mortality it inflicts upon a nematode population. The density of this nematode population is determined before and some time after the treatment. The ratio between these densities is independent of the density before treatment. The effectiveness of a contact nematicide can therefore be determined at any density 
of the nematode great enough to measure the density after the treatment sufficiently accurately. The effect of the treatment on the yield of a crop can be derived from (1) this rate of mortality, (2) the relation between the density of the nematode and the damage to this crop and (3) the effect of the treatment on yield other than by killing harmful nematodes. The latter two relationships must be determined separately.

It is not possible to determine a rate of mortality of a nematode population with relation to a treatment with a systemic nematicide. Therefore the effect of systemic nematicides can only be measured by the improvement of the growth of and the reduction of the rate of multiplication of the nematodes on a test plant. The first depends on the density of the nematode population before the treatment and the second is found by comparing (density dependent) rates of increase with and without treatment. The effect of a treatment with a systemic nematicide can therefore only be determined if the treatment is done over a sufficiently large range of densities and its effects on yield and multiplication can be compared with yields and multiplication rates on untreated plots with a sufficiently large range of nematode densities.

To satisfy these requirements for the experiment reported here a field was chosen where a range of densities of 0 to more than 500 stem nematodes per $500 \mathrm{~g}$ of soil could be expected on an area large enough to contain 140 plots of $1.4 \times 1.4 \mathrm{~m}$. The field chosen was on a sandy loam soil (20\% clay particles, about 5\% organic matter) in West Friesland. The plots were laid out after a preliminary sampling to localize areas with large and small nematode densities. On April 9 and 10 the top $20 \mathrm{~cm}$ of the central square meter of each of the plots was sampled by collecting and mixing together 80 cores of about $20 \mathrm{~g}$. Stem nematode numbers were determined in $500 \mathrm{~g}$ of soil from these samples. They ranged from 0 to 788 . Onions were sown on all plots on April 20 at a rate of $12 \mathrm{~g}$ of seed per $\mathrm{m}^{2}$ in rows $20 \mathrm{~cm}$ apart, the common rate for onions grown for sets. Each of the two chemicals was applied 10 days before and 3 and 6 weeks after sowing the onions. Together with the untreated control this made seven treatments. The 140 plots were therefore divided into twenty blocks of seven plots. The seven treatments were randomly distributed in each block. Each treatment was done over the whole range of densities of the stem nematode occurring in the experimental area (Fig. 7). For the 0,0 diethyl $0-2$ pyrazinylphosphorothioate treatments $2 \mathrm{ml}$ of a $45 \%$ Zinophos emulsion (containing $1 \mathrm{~g}$ of active material) diluted with water to $100 \mathrm{ml}$ was applied per $\mathrm{m}^{2}$ and for the 0-phenyl $\mathrm{N}, \mathrm{N}^{\prime}$ dimethylphosphorodiamide treatments $1.7 \mathrm{~g}$ Nellite $(100 \%$ active material) dissolved in $5 \mathrm{ml}$ ethanol and diluted with water to $100 \mathrm{ml}$. Both preparations were sprayed on the soil surface.

The onions were harvested and numbers of healthy and diseased plants counted between July 22 and 30 . This is a little earlier than normal for sets, but was necessary to be ahead of a disastrous spread of the fungus Sclerotium cepivorum Berk. A large proportion of the plants from the plots treated with "Zinophos" 


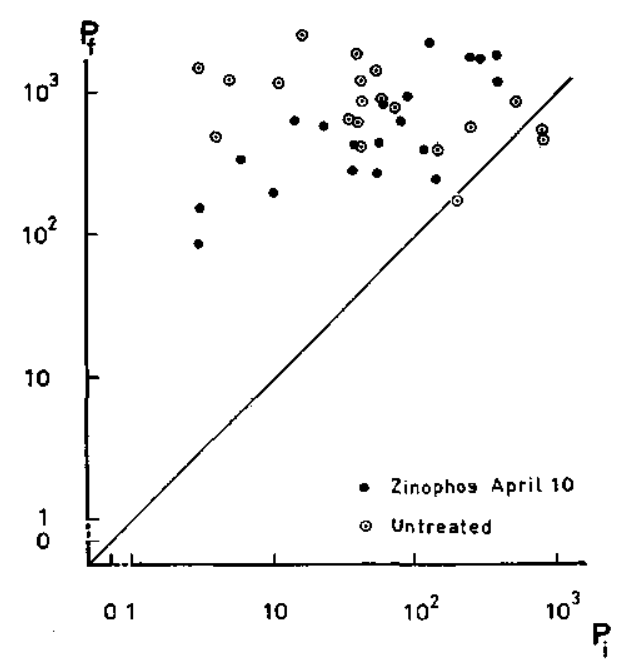

Fig. 1

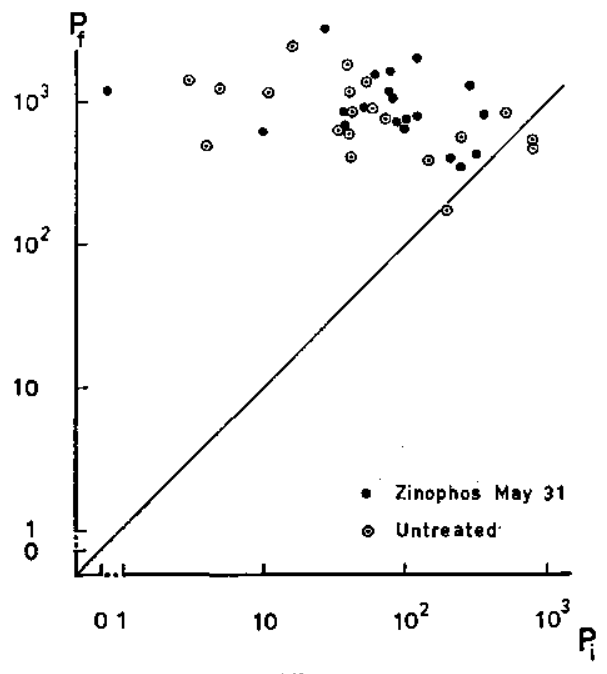

Fig. 3

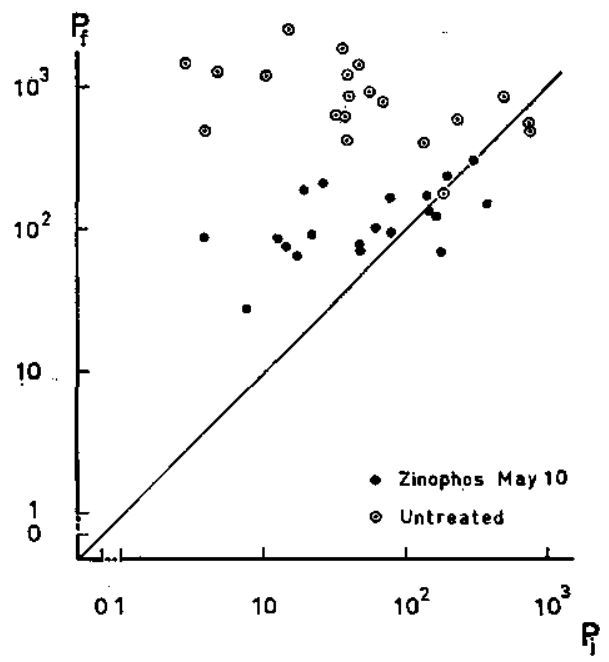

Fig. 2

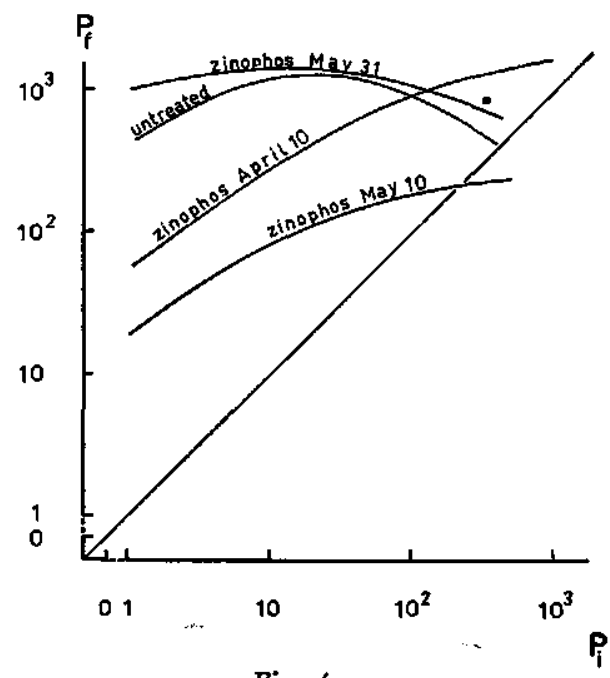

Fig. 4

Fig. 1-3. Multiplication of Ditylencbus dipsaci in onions treated with "Zinophos" on different dates. $P_{i}$ : initial density (number of stem nematodes per $500 \mathrm{~g}$ of soil); $P_{f}$ : final density (number of stem nematodes per $500 \mathrm{~g}$ of soil); in these and all other figures each dot represents one plot. Fig. 4. Comparison of the population increase of $D$. dipsaci on onions after different treatments with "Zinophos".

which looked healthy at harvest time were stored in a cool cellar. They were inspected on Jan. 3, Febr. 5 and March 231964 to determine proportions of diseased onions. Soil samples were again taken from all plots on Sept. 2, to determine stem nematode densities. The diseased plants, which had all been left in the field, had desintegrated by then. The nematode densities found therefore also include the nematodes present in the diseased plants at harvest time. 


\section{RESULTS}

a. Influence of treatments on population density of Ditylenchus dipsaci

The increase of Ditylenchus dipsaci in the untreated plots and those treated with "Zinophos" and "Nellite" are shown in Figs. 1 to 6 . That at a density of one nematode per $500 \mathrm{~g}$ of soil is estimated to have been about 1000 fold on the untreated plots and on those treated with "Zinophos" on May 31. It would probably have been higher yet at still lower initial densities (Fig. 4). It was about 50 fold on the plots treated on April 10 and about 20 fold on those treated on May 10 . On these plots it would probably not have been higher at still lower initial densities (Fig. 4).

The treatment on May 10 had also decreased the equilibrium density 1 ) (about 200 nematodes per $500 \mathrm{~g}$ of soil) below those after all other treatments. It is estimated to have been about 2000 nematodes per $500 \mathrm{~g}$ of soil in the plots treated on April 10, and about 350 nematodes per $500 \mathrm{~g}$ of soil on the untreated plots and those treated on May 31. The latter equilibrium density is much lower than the maximum densities in these plots (obtained at initial densities smaller than 50 nematodes per $500 \mathrm{~g}$ of soil). Most probably so many onions were killed at higher densities of the nematodes (Fig. 7,8 ) that their possibilities to increase were markedly impaired.

\section{b. Influence of treatments on attack of onions by stem nematodes}

In Figs. 7-8, eight numbers of heaithy plants harvested per plot are plotted against stem nematode densities found before onions were sown. On the plots treated with "Zinophos" on May 10 numbers of healthy plants harvested were independent of nematode density. According to Table I only $0.08 \%$ of the harvested plants were attacked by stem nematodes. As only very few attacked plants were noticed in these plots during the entire growing period we may conclude that attack by stem nematodes was very light or absent and that about the same numbers of plants ( 870 per $\mathrm{m}^{2}$ ) would have been harvested on all other plots if these had not contained stem nematodes.

Numbers of healthy plants at very low densities after other treatments than with "Zinophos" on April 10 and May 10 suggest that numbers of healthy plants in the absence of nematodes would possibly have been a little lower after these treatments (estimated at about 670 plants per $\mathrm{m}^{2}$ ) than after the treatments with "Zinophos" on April 10 and May 10 (870 plants per $\mathrm{m}^{2}$ not including five aberrant points) (Figs. 7 and 8). The cause of this difference is unknown. Kaai \& Pronk (1965) found that "Zinophos" gives an excellent control of onion fly (Hylemya antiqua). This may have been the cause of the difference mentioned above.

Total numbers of plants on these other plots were often well below 670 per $\mathrm{m}^{2}$.

1) The equilibrium density is the density at which the population does not increase or decrease (Seinhorst, 1964, 1966). 

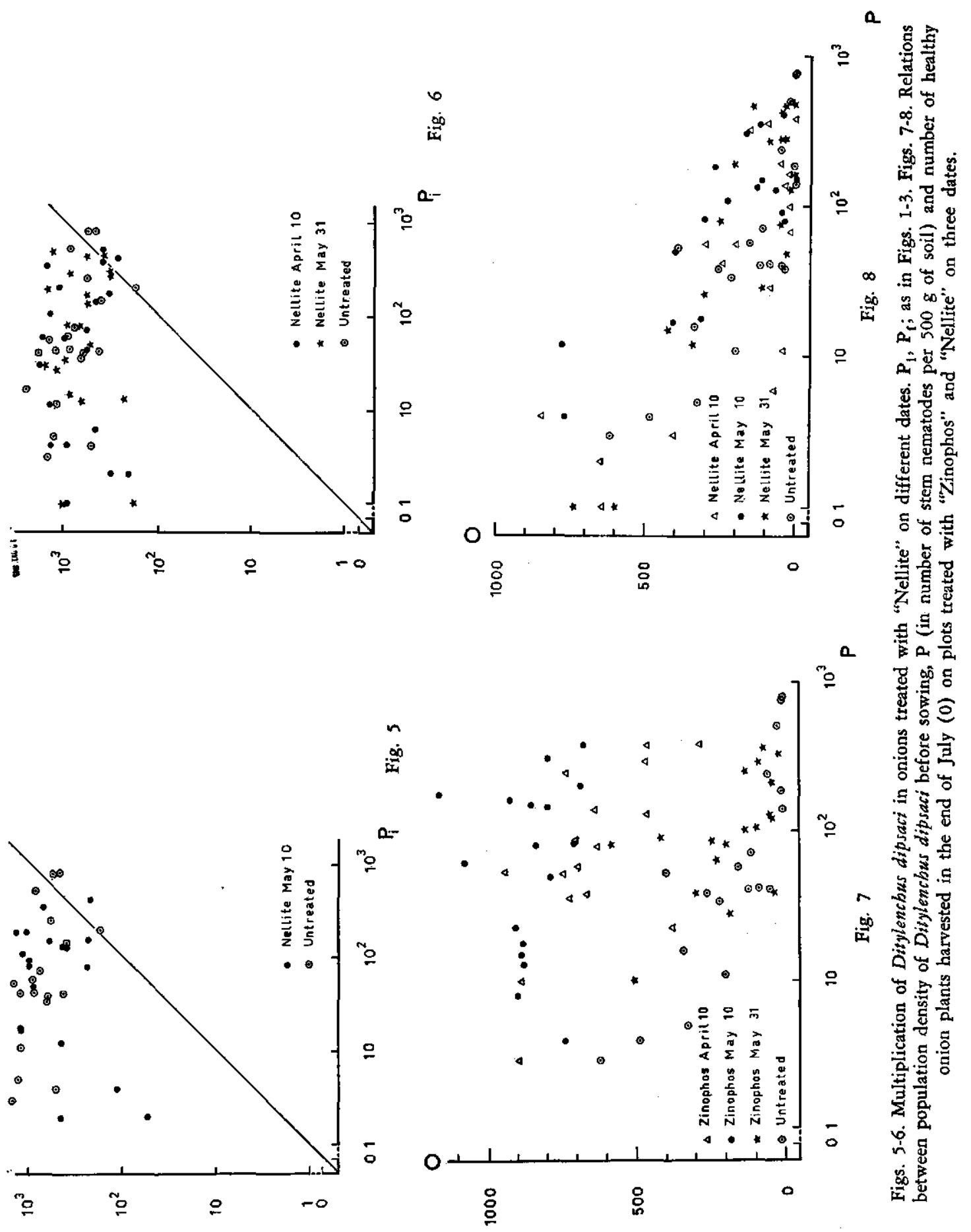
According to Table I the percentage of the plants found attacked by stem nematode at harvest time is greater the smaller the numbers of harvested plants and from 40 times to 200 times the percentage of the plants attacked by stem nematodes on the plots treated with "Zinophos" on May 10. Moreover, according to observations during the growing period stem nematode attack was the only or most important cause of disappearance of plants on most plots. We may therefore assume that the great differences in numbers of healthy plants harvested on these plots are due to differences in nematode attack. There were some exceptions. Some Sclerotium cepivorum attack occurred in all plots, but did not materially decrease the numbers of plants harvested in most. In some plots, all with originally a dense stand of onions (little nematode damage because of low initial nematode density or very succesful treatment), the attack by this fungus was so severe that it did reduce the numbers of harvested plants considerably. Some of these plots were not harvested at all. The numbers of healthy and diseased plants found on others were included in the calculation of the figures of Table I (both healthy and

\section{TABLE I}

Relation between the numbers of plants harvested and the proportions of these that were attacked by stem nematodes

Treatment
(In the absence
of stem nematodes)
Zinophos
Zinophos
Nellite
Nellite
Zinophos
Nellite
Untreated

Date of
treatment
May 10
April 10
May 10
April 10
May 31
May 31

Numbers of plants harvested per $\mathrm{m}^{2}$

(about 870)

773 1)

$\left.628^{2}\right)$

277

234

238

218

210

\author{
$\%$ of these \\ attacked
}

0.08

4.2

10.4

12.6

13.7

14.4

17.0

1) Two plots and 2) three plots with great losses due to Sclerotium cepivorum attack included.

nematode infested plants were killed by the fungus). They are omitted in Fig. 7 and are not taken into account in Fig. 10. That the low yields on two out of 19 plots treated with "Zinophos" on May 10 and on three out of 19 plots treated with this chemical on April 10 were not due to stem nematode attack was not only concluded from the presence of the fungus on the roots of many plants before and at harvest time but also from the very small percentages of plants attacked by stem nematodes in these plots during the whole growing period and at harvest time. On plots that had received other or no treatments there were always considerable numbers of plants attacked by stem nematodes even at low nematode densities. The relation between stem nematode density $P$ and proportion of plants not attacked $y$ is given by the equation $y=z^{P}$ in which $z$ is a constant $<1$ (Seinhorst, 1965). Experimental evidence supports this theoretical relationship (Kaai, 
1964). The relation between densities of the stem nematode before sowing and treatment of more than 20 nematodes per $500 \mathrm{~g}$ of soil and the proportion of healthy plants harvested in the experiment reported here can also be expressed by curves according to this equation (Fig. 10). At these nematode densities Sclerotium

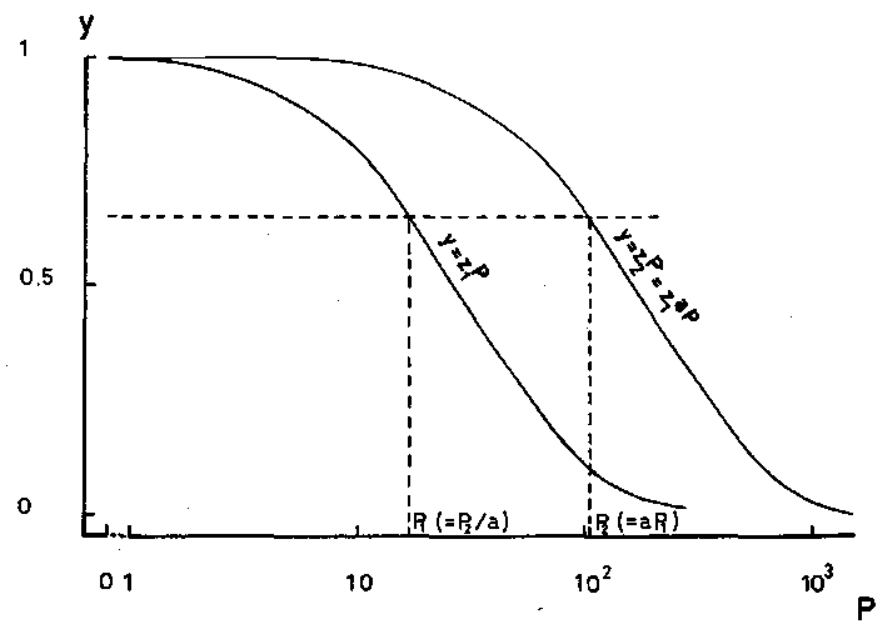

Fig. 9. Comparison of the effects of nematicidal treatments by comparing the relations between nematode densities before treatment and yields.

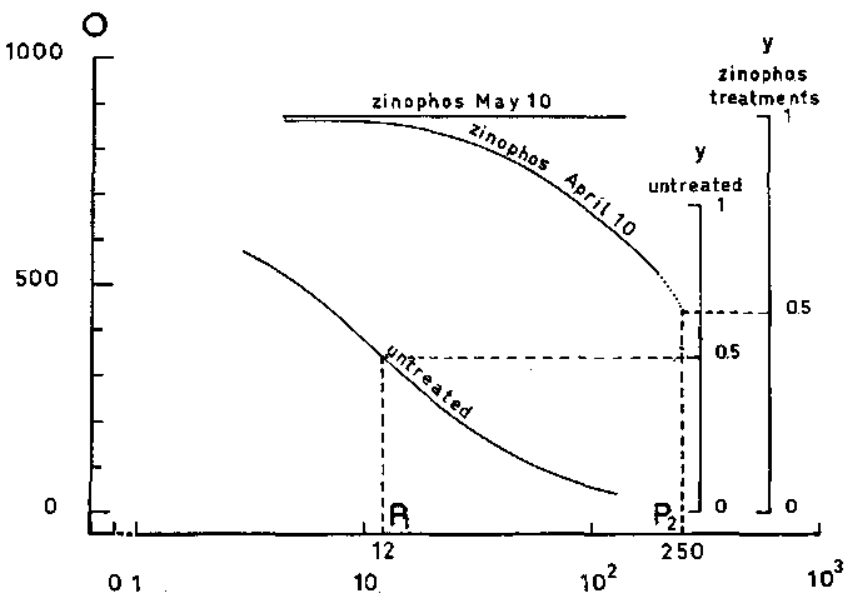

Fig. 10. Idealized relations between population density of Ditylenchus dipsaci before sowing, $\mathbf{P}$ (in number of stem nematodes per $500 \mathrm{~g}$ of soil) and number of healthy onion plants, harvested in the end of July (0), on untreated plots and plots treated with "Zinophos" on April 10 and May 10. The curves are drawn according to the equation $y=z^{P}$. Theoretical numbers of healthy plants per plot in the absence of stem netnatodes on untreated plots (y untreated $=1$ ) $=670$, on treated plots (y zinophos treatments $=1$ ) $=870 . \mathbf{P}_{1}, \mathbf{P}_{\mathbf{2}}$ see text. 
2. Reduction of damage by stem nematodes after application of systemic nematicides

According to Fig. 7 and 10 the application of "Zinophos" on May 10 has protected the onions almost completely against attack by stem nematodes in densities up to 800 per $500 \mathrm{~g}$ of soil. In contrast losses of more than $10 \%$ occurred on the untreated plots at densities over 5 stem nematodes per $500 \mathrm{~g}$ of soil. According to Fig. 10 the effect of the treatment on May 10 was therefore better than that of a contact nematicide that would have killed more than $99 \%$ of the stem nematodes present. This very favourable result is probably due to fairly heavy rainfall just after the treatment (Kaai \& Pronk, 1965). The effectiveness of the treatment with this chemical on April 10 was equivalent to that of a treatment with a contact nematicide that would have killed about $95 \%$ of the nematodes present, that of the treatment on May 31 to that of a treatment with a contact nematicide that would have killed about $60 \%$ of the nematodes present. Of the treatments with "Nellite" only that on May 10 had some effect on the numbers of healthy plants harvested (Fig. 8). It was equivalent to a treatment with a contact nematicide that would have killed about $70 \%$ of the nematodes present. A treatment that does not kill or is not equivalent to one that kills at least $95 \%$ of the stem nematodes is of little importance for the control of stem nematode attack in onions. Further, only great differences in effectiveness can be demonstrated with only twenty observations per treatment. Therefore no attempts

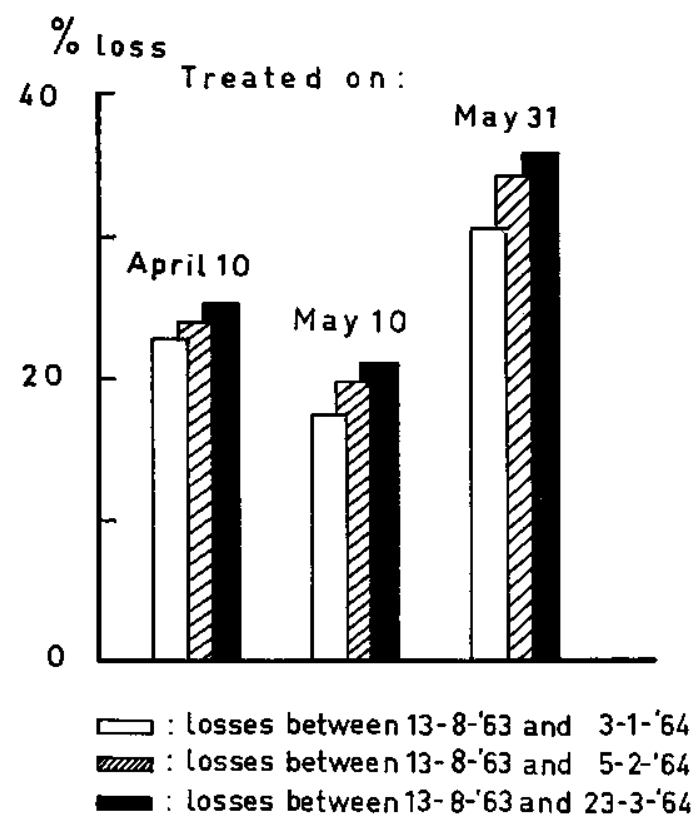

Fig. 12. Losses caused by stem nematodes during storage of onion plants which were still healthy when harvested from plots treated with "Zinophos". 
were made to assess the statistical significance of the differences between the less successfull treatments. That the "Zinophos" treatment on May 10 was very success$\mathrm{ful}$ is obvious also without statistical evaluation. Statistical treatment of the results of experiments on the influence of treatments with systemic nematicides requires calculation of values of $z\left(y=z^{P}\right)$ and their standard deviations.

Even the treatment with "Zinophos" on May 10, that resulted in less than $0.1 \%$ of diseased plants at harvest time, did not protect the onion sets from invasion by nematodes sufficiently to prevent losses during storage. The treatment which gave the highest yield in the field also resulted in the lowest loss during storage (Fig. 12). This suggests that there is a relation between the nematode densities at the time the sets were lifted and losses during storage. If presence of a protective concentration of the chemical in the plants at harvest time had been the cause of the differences in losses during storage, the late treatment with "Zinophos" would probably have given the best result.

The author thanks Mr. C. P. Pronk for his assistance in carrying out the experiment.

\section{ZUSAMMENFASSUNG}

Die Bekämpfung von Stengelälchenbefall in Speisezwiebeln mit 0,0-dietbyl 0.2 pyrazinylphosphorthioat ("Zinophos") und 0 -phenyl $N, N^{\prime}$ dimethylphospbordiamid ("Nellite")

In einem Feldversuch auf leichtem Tonboden, der 0 bis 788 Stengelälchen pro $500 \mathrm{~g}$ enthielt, wurde im Frühling von $1963 \mathrm{zu}$ drei verschiedenen Zeiten $1 \mathrm{~g}$ 0,0-diethyl 0-2 pyrazinylphosphorthioat $\left(2 \mathrm{ml}\right.$ des flüssigen Produktes Zinophos, verdünnt mit Wasser auf $100 \mathrm{ml}$ ) pro $\mathrm{m}^{2}$ auf die Oberfläche des Bodens gespritzt (10 Tage vor, und 3 und 6 Wochen nach dem Säen von Speisezwiebeln). Die Behandlung drei Wochen nach dem Säen gab die beste Bekämpfung von Stengelälchenbefall in Zwiebeln. Eine merkliche Schädigung trat hierbei nicht auf. Auf den unbehandelten Parzellen waren bei einer Dichte von 14 Stengelälchen pro $500 \mathrm{~g}$ Boden schon $50 \%$ und bei 40 bis 50 Älchen pro $500 \mathrm{~g}$ Boden mehr als $90 \%$ der Pflanzen befallen. Diese Behandlung war vergleichbar mit der Behandlung mit einem Kontaktnematizid, bei der mehr als $99 \%$ der Älchen getötet wurden. Auf den unbehandelten Parzellen vermehrten sich die Stengelälchen 1000-fach bei den niedrigsten Dichten, weil die Gleichgewichtsdichte 2000 Stengelälchen pro $500 \mathrm{~g}$ Bodem betrug. Auf den Parzellen, die am zweiten Zeitpunkt behandelt waren, war die Maximumvermehrung nur 20-fach und die Gleichgewichtsdichte 250 Älchen pro $500 \mathrm{~g}$ Boden. Durch die Behandlung wurden die Zwiebeln also schlechtere Wirtspflanze für Stengelälchen. Diese Behandlung war bei geringer Älchendichte vergleichbar mit einem Kontaktnematizid, das $98 \%$ der Älchen tötet und ist bei grosser Älchendichte einer solchen Behandlung weit überlegen. Die Pflanzen von den mit "Zinophos" behandelten Parzellen, die bei der Ernte am 22. bis 30. Juni 1963 noch gesund aussahen, wurden bis mitte März 1964 aufbewahrt. Det Ausfall durch Älchenbefall während der Lagerung war $25 \%$ nach der ersten, $21 \%$ nach der zweiten und $36 \%$ nach der dritten Behandlung.

Behandlungen mit $1.7 \mathrm{~g}$ "Nellite" pro $\mathrm{m}^{2}$ zu denselben Zeitpunkten wie mit "Zinophos" hatten nut wenig Einfluss auf den Stengelälchenbefall der Zwiebeln.

\section{REFERENCES}

KAsI, C. (1964). The relation between population density of Ditylencbus dipsaci and the amount of damage in some crops. Nematologica 10, 72.

KAAI, C. \& PronK, C. P. (1965). Invloed van de hoeveelheid water, waarmee 0,0-diethyl 0-2 pyrazinylfosforothioaat wordt toegediend op zijn werking tegen stengelaaltjes in plantuien. Meded. Landb. Hoogesch. OpzoekStns. Gent 30, 1475-1487. 
OUdEN, H. DEN \& KAAI, C. (1963). Bestrijding van Heterodera rostochiensis en Ditylencbus dipsaci met 0,0-diethyl 0-2 pyrazinylfosforothioaat en VB 744. Meded. Landb. Hoogeseh. OpzoekStns. Gent 28, 638-648.

OUDEN, H. DEN \& SEINHORST, J. W. (1964). De invloed van enkele systemische nematiciden op de vermeerdering van Heterodera rostocbiensis op aardappel en van Tytencborbynchus dubius op stoppelknollen. Meded. Landb. Hoogesch. OpzoekStns. Gent 29, 810-817.

Seinhorst, J. W. (1964). Population dynamics of some root-infesting nematodes. Nematologica $10,61$.

(1965). The relation between nematode density and damage to plants. Nematologica 11, 137-154.

- (1966). The relationships between population increase and population density in plant parasitic nematodes. I. Introduction and migratory nematodes. Nematologica 12, 157-169. 


\section{publikaties van het proefstation}

Door medewerkers van het Proefstation zijn regelmatig Mededelingen en Rapporten samengesteld. Een aantal hiervan is inmiddels uitverkocht. Voor een overzicht van de volledige serie wordt verwezen naar het jaarverslag over 1965 en naar Mededeling 32 (Rond de teelt van knolselderij).

Onderstaand volgt een overzicht van de publikaties die nog verkrijgbaar zijn. Ze worden franco toegezonden na overmaking van het vermelde bedrag op postrekening 619524 van het Proefstation voor de Groenteteelt in de Vollegrond in Nederland te Alkmaar onder vermelding van hetgeen wordt verlangd. Begunstigers ontvangen alle publikaties terstond na het verschijnen gratis.

\section{MEDEDELINGEN EN OVERDRUKKEN}

14 KOOMEN, J. P. en anderen: Rond de teelt van augurken (3e herziene druk) - $f 2,25$ 1962

19 JONGE POERINK, H.: Rand in witte kool - $f 2,25$

1961

24 VAN DER BOON, J., DELVER, P., KNOPPIEN, P. en VISSER, A.: Kalibemesting bij vroege aardappelen in Noord-Holland - $f 0,75$

27 VAN KAMPEN, J. en anderen: 10 jaar P.G.V. - $f$ 2,-

30 WIEBOSCH, W. A.: Jarowisatie bij enige groente- en aanverwante gewassen - $f$ 5, -

31 DELVER, P.: Onderzoek cver de stand van aardbeien in Kennemerland - $f 3,50$

32 KOOMEN, J. P. en VAN DER VEN, C. J.: Rond de teelt van knolselderij - $f 3,50$ 1965

34 BUISHAND, Tj.: Vroege andijvie in de vollegrond - $f 3,-$ 1966

36 BETZEMA, J. en SNOEK, N. J.: Onderzoek bij de teelt van vroege bloemkool - $f$ 3,-

37 SCHONEVELD, J. A.: Arbeidsstudie bij de oogst van asperge - $f$ 4,- 1967

38 BETZEMA, J. en SNOEK, N. J.: Rond de teelt van herfstprei - $f 3,25 \quad 1967$

39 FRANKEN, A. A.: Mogelijkheden voor het vervroegen van asperges (overdr.) - $f 1,-1967$

40 FRANKEN, A. A.: De teelt van asperges - $f$ 4,- 1968

41 VAN BAKEL, J. M. M.: Vallers en kanker in bewaarkool - $f$ 2,50 1968

42 KAAl, C., KOERT, J. L. en HOEFMAN, S. J.: Bestrijding van siengelaaltjes in uien en phlox met 0,0-diethyl 0-2 pyrazinylfosforothioaat en 0,0-diethyl -0(2,4-dichloorfenyl) fosforothioaat (overdruk) - f 1,-

$43 \mathrm{KAAl}, \mathrm{C}$ : Control of stem nematode attack in onions with 0,0-diethyl 0-2 pyrazinylphosphorothioate (,Zinophos") and 0-phenyl N,N' dimethylphosphorodiamide (,Nellite") (overdruk) - f 1,- 


\section{RAPPORTEN}

10 BUISHAND, Tj., DE KRAKER, J. en BREEBAART, mej. G.: Teelt en rassenonderzoek bij tuinbonen in $1963-f 0,70$

13 BUISHAND, Tj. en DE KRAKER, J.: Onderzoek ten behoeve van de groenteteelt voor de verwerkende industrie II - $f$ 2,-

15 BUISHAND, Tj., DE KRAKER, J. en BREEBAART, mej. G.: Teelt- en rassenonderzoek 1964 bij tuinbonen - $f 1,20$

16 BETZEMA, J., JONGE POERINK, H. en VAN DER VALK, G. G. M.: Een studiereis naar Midden-Engeland van $11-18$ augustus $1963-f 1,75$

17 BUISHAND, Tj. en BREEBAART, mej. G.: Rassenonderzoek 1964 bij stamslabonen, stoksnijbonen en spekbonen in Beneluxverband - $f 1,75$

18 DE KRAKER, J. en BUISHAND, Tj.: Teelt- en rassenonderzoek bij tuinbonen in $1965-f 1,50$

19 VERLAAT, J. G.: Ervaringen bij het onkruidbestrijdingsonderzoek in de volle gronds groenteteelt in 1965 - $f$ 4, -

20 BUISHAND, Tj., DE KRAKER, J. en COMMANDEUR, J. C.: Gebruikswaardeonderzoek van spinazierassen in $1965-f 1,50$

21 SCHONEVELD, J. A.: Arbeidskundig onderzoek bij het centraal sorteren van asperge - $f 1,75$

22 BUISHAND, Tj.: Teelt- en rassenonderzoek bij suikermais in 1964 en $1965-f 1,75$

23 BUISHAND, Tj. en DE KRAKER, J.: Teelt- en rassenonderzoek bij sla-, snij- en spekbonen in 1965 - $f$ 2, -

24 SCHONEVELD, J. A. en URSEM, C. Th.: Arbeidskundig onderzoek bij het oogsten en transporteren van sluitkool - $f 2,50$

25 SCHONEVELD, נ. A.: Onderzoek naar de werkmethoden bij witloftrek - $f 3,50$

26 WIEBOSCH, W. A.: Aspecten van het gebruik van omhuld zaaizaad, zogenaamd pillenzaad - $f$, -

27 SCHONEVELD, J. A.: Kwaliteit en arbeidsproduktiviteit bij machinaal sorteren van asperge met de "Sortair" - $f$ 1,50

28 VERLAAT, J. G.: Ervaringen met chemische onkruidbestrijding in de vollegronds groenteteelt in $1966-f 4,-$

29 VLUG, J.: Teelt- en rassenonderzoek bij sla in 1966 - $f$ 2,-

30 KOOMEN, J. P. en VLUG, J.: Bodembedekking met plasticfolie bij augurken $-f 1,75$ 